\title{
'Re-grabbing' marine resources: a blue degrowth agenda for the resurgence of small-scale fisheries in Malta
}

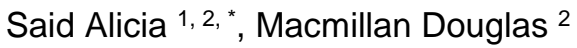

1 IFREMER, Centre for Law and Economics of the Sea, IUEM-AMURE, Brest, France

2 School of Anthropology and Conservation, University of Kent, Canterbury, United Kingdom

${ }^{*}$ Corresponding author : Alicia Said

\begin{abstract}
:
The era of blue growth, underpinned by neoliberal policy discourses, has been pervasive in the promulgation of European marine governance and policies in the past decade, with little or no regard for the sustainability of small-scale fisheries. In this paper, we engage with theoretical and empirical observations to reflect on how the promise of sustainable economic growth arising from the convergence of international conservation policies and the blue growth paradigm, has failed to materialise and caused huge social and economic inequities among local fishing communities and the catastrophic disruption of the socio-ecological system of fisheries. Drawing on various interventions in Malta, we illustrate how neoliberal policies, lauded and promoted as part of a national blue growth strategy, are suffocating and marginalising small-scale fishing communities by concentrating fishing opportunities into fewer, larger corporate hands, and by a hegemonic anti-small scale fishing narrative that seeks to replace traditional fishing with the 'darlings of the new blue economy', aquaculture and coastal tourism. With artisanalcommercial fishing in Malta on the verge of extinction, we call for reversal of neo-liberal policy measures to re-create a more resilient and stable fisheries economy through specific blue degrowth measures including improved access to fisheries resources and markets, and the establishment of marine protected areas that recognize the value of small-scale fisheries to conservation. This could be achieved through equity-based governance systems, including improved profit distribution systems within community economies, that grant small-scale fisheries the possibility of re-institutionalizing their sector and promoting their existence and viability into the future. Ultimately, we demonstrate that through a blue economy roadmap for small-scale fisheries, small-islands states like Malta, can rescue an important component of their maritime traditions, and be better placed to reach the obligations set out within the United Nations sustainable development goals.
\end{abstract}




\section{1) Introduction: Small-scale Fisheries in the Blue Growth Era}

Fishing communities around the world have been undergoing a number of enforced adaptations due to a much changed policy landscape that favour economic efficiency and marine conservation objectives. This has been achieved by the privatisation of fishing rights, the establishment of marine protected areas, and the allocation of new 'development' rights to marine farming and tourism interests. These new forms of institutionalized approaches, collectively informing the governance of marine resources, have created a new era of hegemonic governmentality, which, we argue, can lead to greater conflicts than those the policies were intended to address and, has in some cases, led to the destitution of fishers. As Bresnihan (2019) elaborates the introduction of neoliberal policies such as quotas, rationalization and conservation are likely to bring with them a dysfunctional situation whereby 'overlapping apparatuses of neoliberal governmentality' are not sufficiently connected to the complex realities that shape the fishing communities and are thus unable to account for the interactions between the 'market, the marine environment and the individual motivations of fishers' (Bresnihan, 2019, p. 158). As a result, small-scale fishing communities are finding it increasingly difficult to retain their fishing activities, mostly because the new governmentality has limited fishers' access to fish resources and fishing grounds, denying their right to catch (e.g. through restrictive tuna quotas) and by encouraging new uses to proliferate on hitherto indigenous fishing grounds in the coastal zone.

Considered as 'anachronistic' anomalies (Sabau and van Zyll de Jong, 2015) and barriers to efficiency in the sector (Gibbs, 2007), small-scale fisheries have been facing challenges to retain their position within many fishing communities across the globe (Davis, 2015; Pinkerton and Davis, 2015; Sumaila, 2010). This is because economic-efficiency and growth strategies, facilitated by neoliberal policies, tend to push towards capitalistic production systems which ultimately terminates low-capital-based enterprises characteristic of small-scale fisheries fishers either have to scale up quickly or leave the sector, as seen in the fishing ports of Denmark (Host, 2015), the UK (Donkersloot and Menzies, 2015), Spain (Lloret et al., 2016) and Norway, and Greenland (Jacobsen and Delaney, 2014). For example, individual transferable quotas (ITQs), introduced to manage fish stocks have created market-based governance systems that turned fishing rights into property assets that can be easily transferred into the hands of the wealthy through a process of 'accumulation by dispossession' (Harvey, 2004). These systems, led by top-down state-led strategies, are informed by scientific advice and models, but legitimized through the participation of fisher 'representatives' (who are often those with most power to gain). However, their 'fitness for purpose' on the ground where they are implemented remains questionable (Bresnihan, 2017). 
The implementation of marine protected areas has also been criticized for facilitating appropriation and dispossession under the guise of marine conservation especially when new forms of activities such as ecotourism are implemented at the expense of artisanal fishing practices and the continued existence of local communities (Coria and Calfucura, 2012; Duffy, 2002; Hill, 2017). Similar trends of accumulation have been noted in the 'grabbing' of the ocean space (Bennett et al., 2015) for marine activities to accommodate new uses including aquaculture, tourism, and offshore energy leading to intensified congestion and squeezing out of traditional communities from their own grounds (Hadjimichael, 2015; Said et al., 2017). This process, taking place through seafloor privatisation mechanisms driven by big industries, is accelerating at a fast pace (Jentoft, 2017). In the past decade, this push towards privatisation has increased, however, the process has been somewhat camouflaged by 'blue washing' narratives around 'blue growth' or 'blue economy' that portrays a future of sustainable marinebased economic growth for generations to come (Barbesgaard, 2018).

In the context of the EU, for example, the blue growth agenda is about the development of sectors that allegedly have a high potential for sustainable jobs and growth including aquaculture, coastal tourism, marine biotechnology, ocean energy and seabed mining (EC, 2017). Fisheries do not feature in the priority areas of blue growth, with the argument that fisheries growth plans go against any conservation strategies targeted towards replenishing and recovering fish stocks (Blomeyer et al. 2017). As a result, coastal communities as fishingdependent economic enterprises are not welcome in the blue economy (at least in the European context). Although presented as a progressive and sustainable concept, blue growth is also legitimising social injustice among traditional fishing communities who tend to be relegated from the formal process of marine spatial planning, that sketch out the future of marine spatial use within national and regional seas (Brown et al., 2015).

Criticizing blue growth as 'blue grabbing' various scholars have spoken about the dark side of the agenda (Benjaminsen and Bryceson, 2012; Bennett et al., 2015; Hadjimichael, 2018). In fact, one could argue that 'blue growth', is a logical extension of the neoliberal efficiency capitalist-ridden model that has suffocated the continuation and growth of small-scale fishing enterprises, and is likely to bring further derailing effects on the resilience of artisanal fishers around the world. Referring to this era as the 'capitalocene', Moore (2016) argues that the constant accumulation of capital is coming at a cost to nature and society risking the income and well-being of more vulnerable groups. Such inequalities of globalisation are a threat to social sustainability (Koning, 2002). With a focus on capital efficiency and conservation ecology that does not recognise human dignity, culture and community wellbeing as policy objectives, fisheries and marine governance are crippling communities' ability to sustain themselves through resource starvation. 


\subsection{The Blue Degrowth movement}

Critiques of 'growth' have argued for a reconsideration of this growth model and a significant redirection of global development trajectories (Berkes et al., 2006; Costanza and Kubiszewski, 2014), such as the 'Degrowth' movement, an equity-driven downscaling of production and consumption, which gives more space for the role of collaborative or social economies that are not focused on mass capitalistic growth, with the aim of increasing human wellbeing, and improving ecological conditions (Martínez-Alier et al., 2010). This concept has been recently extended to the marine realm with a proposition of a 'blue degrowth' agenda as an anti-thesis to the blue growth one (Hadjimichael, 2018). What this could mean in terms of fishing communities is not a downscaling of the activities of small-scale fisheries, but more of a system of diverse economies (Gibson-Graham, 2008) where the small-scale sector can remain viable by having better access to fishing rights, and be protected by a system that ensures their survival, away from the current monopolistic system that channels profits to big industries. This could be achieved through fisheries governance which has the communities needs at the heart of the fishery management, such as the implementation of non-tradeable community-based quotas instead of ITQs (Foley and Mather, 2016), the implementation of marine protected areas with the needs of fishing communities in mind (Jones, 2009) and the creation of niche markets that give a breathing space to communities to flourish in the midst of capitalistic growth (Knutson, 2017).

In this article we argue that small-scale fisheries within a blue degrowth system could offer a ready-made solution to the problems fuelled by capitalistic growth including depletion of fish stocks, accumulation of wealth, wiping out of fishing communities, social breakdown and associated socio-ecological difficulties. In other words, degrowth offers a landscape where access to the commons is defined on equity, and where the economy 'rhymes' along the lines of prosperity that is not only calculated on growth through GDP and job creation (MartínezAlier, 2012). It does not envisage a future with 'no growth for all', or a return to the past, 'but a mobilization of elements of the past into the present and future' (Kallis and March, 2015) where the economies are more democratic and inclusive, support ecological thresholds and the wellbeing of society. So instead of focusing on efficiency and resilience through monetary returns and economic capital production, degrowth puts the social, ecological and economic dimensions on an equal platform with the aim of truly achieving what we mean by sustainable development (Hadjimichael, 2018).

Despite being around for a number of decades, degrowth as a concept has not yet materialized in policy or practice (Kallis and March, 2015) mostly due to the epistemological differences that create ambiguities of what it ought to achieve and how it should be 
implemented (Martínez-Alier et al., 2010) and the lack of political will to halt the 'neoliberal efficiency' trend which seem to have taken over the fisheries and marine governance agenda ${ }^{1}$. Although a huge overhaul in the economic system is not on the horizon, a planned degrowth strategy for the fisheries economy could provide the guiding exemplar of how degrowth can actually work to re-gain prosperity and viability in communities that actually depend on the sustainable management of natural resources for their livelihood (Pauly, 2017). In some important aspects the potential of degrowth in fisheries might help the sector reformulate the policy objectives of decreasing capacity and controlling effort, and protect fish stocks ${ }^{2}$. Crucially though, degrowth also points to a direct shift away from the forces of privatisation and accumulation by capitalisation, through innovative ways of fisheries management that could sustain local economies. In simplistic terms this would mean a redistribution of resources from the currently concentrated hegemonic economies, to the local communities, through the concept of 'community economies' (St Martin, 2007).

Moving towards more inclusive economies would secure a better place for small-scale fisheries in the blue economy, and facilitate the pathway towards achieving the UN SDGs (Cohen et al., 2019). In other words, by aligning fisheries and marine governance to support more social and inclusive economies, as conceptualized by the blue degrowth movement, would also assist governments to satisfy other sustainability pillars including sustainable communities (SDG11); economic growth and decent jobs (SDG8); strengthened institutions (SDG16); access to fish resources (SDG14) and to food security (SDG2); as well as improved wellbeing (SDG3). Realizing potential governance transformations to achieve such goals would however require a broader understanding and consideration of the barriers that exist between different objectives e.g. reducing inequalities (social sustainability) vs. economic growth (economic sustainability) or achieving conservation (ecological sustainability) vs. retaining community viability (social sustainability) (Said and Chuenpagdee, 2019). This also includes looking at the possible constraints operating at different governance scales from individual to global which would determine implications and success of new alternatives (Gritzas and Kavoulakos, 2016).

In this article we take Malta as a case study to discuss the opportunities and constraints for a new model of economic growth, in line with the degrowth ideology, by looking in depth at the marine policy framework in the context of small-scale fisheries. First we detail how the current growth model has impacted on the sustainability of the small-scale traditional fishing sector,

\footnotetext{
${ }^{1}$ This is especially the case in Europe with the support of the centrist and right-leaning political parties, who seem to be the most influential political groups (Gidron, Noam; Ziblatt, 2019)

${ }^{2} \mathrm{~A}$ case in point is the EU failed target of reaching MSY of stocks by 2020 (European Environment Agency, 2019).
} 
and then describe how the situation can be reverted through innovative degrowth economic principles. Specifically, first we explain how corporate growth in the fishing sector, as well as the advent of new spatial uses within indigenous fishing grounds are pushing out the artisanal fishing fleet. We do this by referring to published work that interrogates the rise of phenomena such as the growth in the bluefin tuna fishery (Said et al., 2016), the rapid expansion of the recreational fleet (Said et al., 2018b), as well as the advent of marine protected areas within the coastal fishing grounds (Said et al., 2017). In all cases, we illustrate how the different policies implemented as part of the marine and fisheries conservation and efficiency strategies, have been suffocating the regeneration of the small-scale fishing communities. The paper goes on to highlight how a 'governance reset' in line with a re-grabbing degrowth agenda could reinstate the artisanal sector as a fully-fledged sector of the local blue economy and proposes measures of how this could be achieved through imaginative and practical ways.

\section{2) Methodology}

This paper is based on a review of existing theories and thinking from the published literature, contextualised and substantiated with fieldwork data collected in the field between 2014 and 2015 in Malta. Further engagement in Maltese fishing ports has taken place between 2016 and 2018, with the main author maintaining information updates from the key informants. In total, since the inception of the study, a number of formal $(n=47)$ and informal $(n=123)$ interviews were conducted with Maltese fishermen both at sea, and in their workshops' premises. Co-incidental meetings also took place in cafes and bars and at fishing ports. Participant observation during fishing trips was also integral to the research effort as it provided an opportunity to delve into the realities of policy-related matters. The main author's previous acquaintance with the field was important to establish the necessary trust and gain access to key informants in the fishing communities. Speaking the same language and dialect as the fishers, placed the researcher at an easier stance approaching individuals and gaining the tacit understanding of particular oral statements and attitudes that are inaccessible to "professional outsiders" (Agar, 1996).

Ethical considerations ${ }^{3}$ were taken into account throughout the data collection process, especially during happenstance encounters for these elicited rather tacit and sensitive information. The use of gatekeepers was essential for accessing different networks of fishers through purposeful snowballing. Rapport with the fishers was well-established to an extent that they themselves were making direct requests to be interviewed by the first quarter of the fieldwork. The primary data was triangulated with other sources including online forums, media

${ }^{3}$ The data collection process was aligned to the code of ethics of the American Anthropological Association (AAA). 
articles, local and regional legislations, and formal national statements, including Ministerial speeches. Detailed information about the fishing sector was kindly provided by the Department of Fisheries and Aquaculture (DFA), within the Ministry for Sustainable Development, Climate Change and the Environment, and also accessed via publicly available statistical database systems ${ }^{4}$. Following the compilation of the various datasets, an open-ended comparative technique based on the grounded theory approach was implemented to triangulate the data so as to assure that the findings were consistent, valid and reliable.

\section{3) Blue Grabbing: Neoliberal landscapes in the small-scale fisheries of Malta}

The fishing sector in Malta has changed radically in the past 20 years, with the fishing fleet decreasing from 1850 vessels to 1002, predominantly through policy reforms that have led to a much higher concentration of vessel ownership and fishing rights. Currently the fleet is composed of 935 small-scale (>12 metres) and 67 large-scale fishing vessels; with different levels of investment and fishing capacity, depending on the fishing rights that the owner has, including bluefin tuna, swordfish, dolphinfish, and coastal fisheries. Around $50 \%$ of the bluefin tuna quota, which is the most profitable fishery, belongs to around 6 operators, with the rest split non-homogenously amongst less than $50 \%$ of the total fishing fleet (Said et al. 2016). The ownership of vessels varies across the sector, ranging from owner-operated vessels (1-2 vessels) to multiple ownership (2-4 vessels) vessels by small fishing companies; and the large corporations owning both large-scale and small-scale vessels (4 or more). This reorganisation began in earnest in 2004 with the ratification of the relevant EU legislation which promoted the 'efficiency led model' encouraging the replacement of artisanal vessels by larger industrial ones. Parallel conservation measures such as the rise of the 'no-commercial catch' recreational sector also contributed to the decline of the small-scale sector (Said et al., 2018b).

These new laws replaced customary fisheries governance measures that had been in place since 1934 through the national fisheries legislation (National Law 425), creating new forms of governmentality that did not necessarily fit the resilience of the fishing communities at large (Said, 2017). Although represented as policy tools for sustainability, the new systems of governance altered power relations that favoured specific groups and individuals to the detriment of others (Said, 2017). The former includes fishers' 'representatives', who legitimized the implementation of policies through processes of 'mutual' decision-making. Big external investors also gained a strong foot hold in Maltese waters for example, through the issuance of new licenses for trawlers and purse seiners that had hitherto been kept low in

\footnotetext{
${ }^{4}$ ICCAT website (https://www.iccat.int/en/) and the National Statistics Office, Malta (https://nso.gov.mt/en/Pages/NSO-Home.aspx)
} 
numbers, and reserved for few local operators with additional protective measures to safeguard the artisanal fishers (Camilleri, 2002).

\section{1) Fleet grabbing}

The first process of acquisition that has taken place within the fishing fleet happened in the context of the vessel ownership system after the government, in 2004, implemented a restructuration process to replace what were deemed to be inactive' and 'low-income-nature' vessels with 'economically efficient' vessels in an endeavour to 'rationalize' the fleet. This was done because, following EU accession, the gross tonnage (GT) and kilowattage (KW) of the fleet was capped, disallowing the government from issuing new fishing vessel licenses. The process of restructuration was done mostly as a way of removing small-scale vessels from the national GT and KW to make space for the large-scale vessels. This restructuration, which also led to the introduction of a recreational small-scale vessels fleet purposely formed to accommodate around 800 vessels as 'compensation' for lost rights (Said et al., 2018c)

remains highly contentious amongst the fishers' community (Dimech et al. 2009). The increase in trawlers led to pressure on fish stocks, and despite being framed as sustainable resource management, recent statistics shows that there has been a radical decline in stocks (MSDEC, 2013), thereby affecting the ecological integrity of coastal fisheries and the stocks available for the artisanal counterpart. Moreover, in the past decade, the fleet has been moving from owner-operated family-owned enterprises to company systems where even small-scale vessels are increasingly becoming owned by corporate industries. The high price attached to these vessels have become a significant barrier to entry for the younger generation many of whom are forced to fish (illegally) through recreational vessel licenses. "I would like to buy a commercial boat permit so I can legitimately sell my fish, but today I have to decide whether I get a mortgage for a boat or for a house. I cannot do both" (Recreational fisher, 2016).

\section{2) Bluefin tuna grabbing}

Caught exclusively by artisanal long-liners for decades, bluefin tuna has played an important role in sustaining the local fishing communities. However, with the advent of the tuna recovery plan in 2009, many artisanal fishers were pushed out to make space for the industrial tuna ranching operators, enabled by privatisation policies introduced by the Government. This was decided following a drastic reduction in fishing opportunities through the EU Bluefin tuna recovery plan, which instigated the implementation of individual transferable quotas (ostensibly to achieve an efficient balance between the number of vessels actively engaged in Bluefin tuna fishing and the fishing opportunities set in the national total allowable catches or TACs). In this drive for efficiency, the purse seine industry, which captures live tuna for tuna fattening ranches, was the predominant player that bought out and rented more than half of 
the national TAC, and thus amassing profits that accrued from the Bluefin tuna sector (Said et al., 2016).

This capitalist model has shifted fishing rights into tradable property, making it difficult for small-scale fishers to compete for what where once 'their' fishing rights, thus highly impacting their income .Fishers faced with dwindling returns moved their effort to fishing non-quota species, and as non-quota species are not monitored, there are no catch limits on such species which is leading to increased pressure on these stocks and thereby risking these stocks being fished at unsustainable levels. This pressure on income is driving the nonmonitored fishery down an unsustainable pathway - As one fisher argued, "The smaller artisanal boats, which depend much on this type of fishing, usually carry 10 to 12 pieces of nets but there are now the bigger boats carrying 50 to 70 pieces of nets and working round the clock, thanks to imported cheap labour." (Caruana, 2015 - Newspaper article).

Some positive changes have taken place in 2018 following an increase in the national TAC, with new licenses for the Bluefin tuna sector given to 52 small-scale fishers with an average quota of $750 \mathrm{~kg}$ tuna each ${ }^{5}$. However, the tuna fishery governance system is still very much controlled by, and aligned to support, the tuna ranching industry, which holds control over the largest chunk of the tuna exports and the millions of Euros profits therein (see. NSO, 2015) and it is unlikely that the existing inequalities in the distribution of tuna-generated wealth will be reversed under current measures.

\section{3) Coastal Grabbing}

In inshore waters, fishers constantly face congestion and are increasingly unable to continue their fishing practices within their traditional fishing grounds. Dealing with competition for space with oil bunkering, shipping routes, infrastructure, tourism and recreational fisheries, the artisanal sector is becoming squeezed out (Said et al., 2017). The recent national plan for land reclamation, which seeks to extend the size of the Maltese islands through landmass creation on the seabed (and on fishing grounds), has triggered further fear amongst the fishers who have signified the catastrophe that can emerge in the fishing economy if such plans are materialized. "We are already squeezed into narrower fishing grounds thanks to oil bunkering, tuna pens and other coastal activities, let alone having more of the coastal areas rendered inaccessible." (Fisher in Maltatoday 20186).

\footnotetext{
${ }^{5}$ Around 3 to 4 tunas for the whole season, equating to app. $€ 7000$ in landing value per vessel. 
This comes along concurrent plans for more seafloor grabbing for the implementation of marine protected areas (MPAs) which are set to encompass $42 \%$ of the inshore fishing grounds, and within which ecotourism is depicted as a new blue economy niche, which allegedly would provide diversification opportunities to small-scale fishers. Conflict over this form of blue grabbing has escalated, as fishers feel victimised by new economic niches that are implemented in the name of marine conservation without proper government consultation (Said et al., 2018).

\section{4) The cost of Blue Grabbing: Fragmentation and disenfranchment of fishing communities}

As illustrated in Figure 1, our research has found that the policies have changed the landscape, fragmenting the fleet into different segments including those at the top who are prospering through the new policies as they were able to have direct access to decision-making pertaining to access to resources (quota ownership, subsidies, fishing vessel licenses) others that are persisting by engaging in long hours of work and making ends meet through part-time jobs on land, and others that started perishing and leaving the sector altogether (Said et al., 2018).

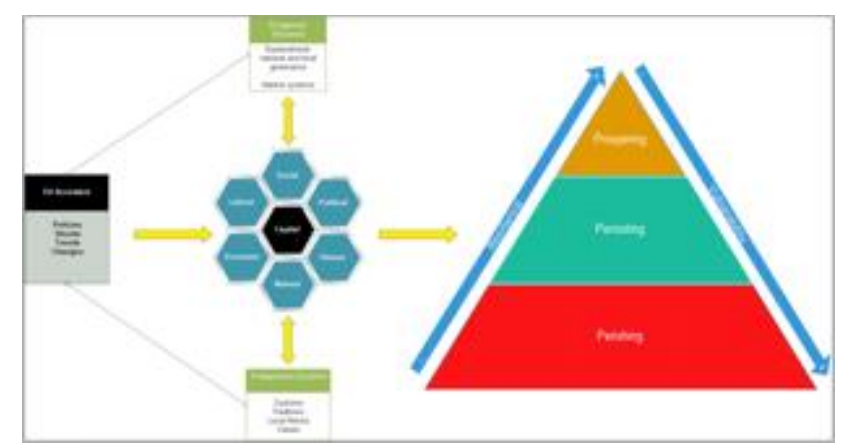

Some have joined the large vessels as employees, while others are now employed at the tuna ranching farms, on a payroll that does not equate to the income of being independent fishers. Fishers feel that they lost their independence as it is becoming difficult to survive in a sea 'full of capitalist sharks', (Fisher, 2015). "My grandfather and my father were fishers... but I do not want my son to be a fisherman, because there is no future for him - it is better if he goes to university and finds a good job" (Fisher, 2015). Despite their assurance that the fishing offers no future, indepth conversations with fishers shows that they still feel remorseful about being the first generation not to pass on the family ancestral legacy of fishing. Disenfranchising of the fishing community is also happening with the disappearance of the owner-operated concept of familybased enterprises operating through profit-sharing systems where profits were shared amongst the crew. This concentration of the fleet ownership is now giving way to a more capitalistoriented system with the engagement of labour to support the vessel operations. "The vessels are now becoming owned by the corporate industries, and we [ex-fishers] have to join in as the workforce" (Fisher, 2016). 
Although some may argue that this is a good strategy as fishers have more peace of mind as they become employed on a payroll and do away with the economic risks that an enterprise brings with it, this does not seem to be always the case. A visit to the Maltese fishing ports shows how the vessels, both small-scale and large-scale, are increasingly becoming crewed by foreign low paid labour rather than local deckhands. "Boats are full of Indonesians and Northern Africans; these people have become the new fishers, not us" (Fisher, 2017). The operators of the boats explain that "we have to rely on foreigners because it is difficult to find local fishers to operate the vessels". (Fisher, 2016). The payroll system is one of the strategies that the fishing operators have adopted in a highly-competitive sector where going 'big' is the only hope to remain an active fisher. This demonstrates that the fishing sector has moved, or been pushed, to a new era where survival is determined by one's capacity to grow, and where individual enterprises, with economic and/or political capital, have become favoured through systems that rewarded economic efficiency at the expense of social sustainability of fishing communities. This can be seen in the ruptures created within the fishing communities, including torn families who have been divided by a system of quotas that reproduces inequalities within the sector. "Here you find brothers who don't talk to each other because of quotas and vessels, it is sad to see how the sector has become so fragmented" (Fisher, 2016).

The co-operatives, whose role is to represent the needs of all their members, have also contributed to this fragmentation, by putting the interests of the few within the upper echelons of the fishing community before the communal good of the entire membership (who they ought to be representing). The most illustrative case involved in the establishment of a tuna ranching farm by one of the co-operative leaders back in 2009 (as a private enterprise), using his 'fishers representative's hat' to support the process, by claiming, as quoted by a local newspaper that "...the proposed project would be of benefit to fishermen", and that, "if approved, it would be the best Christmas present for fishermen" (Independent, 2005). Primarily at the mercy of the high-handed decisions taken on their behalf, powerless fishers feel that the tide has turned against them, and there is nothing they can do. Even though some seem to be conscious of their situation, they perceive themselves as the 'small fish' who are unable to change their destiny. In a fisherman's words: "I understand that the small fish never ate the big fish, and thus we are not going to be able to overturn the situation" (Fisher 2015 in Said et al 2016).

Small-scale fishers faced by dwindling opportunities, are at times being forced to commit illegal fishing to make income, such as landing illegally caught species, fishing in conservation areas, or engaging in quota busting. This puts them in a situation of constant fear that affects their wellbeing, especially when they are reported for their illicit activities by fellow community members. "We need to be cautious when we bring in the (illegal) fish, because you do not know who is your friend" (Fisher, 2015). While this sense of distrust between community 
members has disintegrated the social cohesion, fishers have also become portrayed by society-at-large as selfish criminals and poachers who are contributing to overfishing and invading pristine ecosystems, as depicted by newspaper articles from time to time (TOM, 2014, 2011, 2010, 2007a, 2007b). This mostly happens when fishers are sighted fishing within traditional fishing grounds that have become designated for diving.

The introduction of marine protected areas may also exacerbate the crisis facing the artisanal fleet as evidenced at the AMARE workshop held in June 2019 (TOM, 2019). With fishers feeling that the MPAs' consultations with the authorities are not sufficient and that the conservation objectives are being drafted through a narrow ecological vision, they currently have no guarantee regarding that fishing livelihoods will be protected following the establishment of the MPAs. Even though, through the right management framework, smallscale low-impact fishers can, in principle, provide the right extraction balance within the context of marine conservation, no proper conversation on how to put fishing at the centre of marine conservation plans has been enacted, leaving the fishers strongly resistant towards the MPAs (Said et al., 2018).

The research shows how the different drivers, emanating from the marine and fisheries policies are affecting the resilience of the fishing sector, and the current state of affairs does not auger well for future fishing communities as a fully-fledged vibrant socio-ecological system. The fleet is now ageing, "...the average age of fishermen is over 50 ...traditional fishing is dying out, and many artisanal fishermen are having to resort to making money on the side as water taxis, ferrying tourists around the bay..." (Fisher in Borg, 2017). In some cases, fishers have found the option of leaving the sector and moving into tourism, such as being boat-drivers or tourist operators, as a better alternative for their incomes. This however is a viable option when fishers can secure a good deal for their fishing vessels, especially from large companies who are ready to pay staggering prices for the vessels. This prompts questions on the future of the fishery and the entry barriers that the younger generation is facing to enter the fleet as owner-operators, given that the price of vessels especially with tuna permits, has in some cases also reached the Euro 1 million (Personal communication with a fisher in 2017).

Dynamic changes in the ownership patterns and the sharp reduction in owner-operated fishing enterprises, are key indicators of failure in the current market-based governance system, cumulatively leading to what could become the extinction of maritime traditions. Although some changes have taken place in the past year, including the increase in the number of permits in the Bluefin tuna sector (Martin, 2019), and the financial assistance to support fishers 
in diversification plans ${ }^{7}$ (Pace, 2019), these are still cosmetic changes that do not provide the real resources needed to retain the viability of the fishing communities.

\section{5) A Blue Economy for Fishing Communities - The Road Map to Change}

Our research shows that the tribulations that are currently hampering the resilience of the fishing sector are not being given sufficient attention, mostly because the sector seems to be strictly managed through a top-down fisheries ecological-economic strategy that does not understand the viability constraints and needs of the small-scale fishing sector. Moreover, the sector is also caught in a whirlpool of legal pluralism hailing from the marine conservation policies of the habitats directive, and the blue growth strategy that does not consider the small-scale fishing sector as one of its thematic areas. With a lack of knowledge on how the small-scale sector can be part of, rather than an anomaly, within the future of conservation and blue economy, there is no real assurance of how the small-scale sector can survive within the new policy agendas surrounding the maritime sector. Even though the EU is enacting various policies with the small-scale fisheries in mind, such as the MedFish4ever campaign in the context of the Mediterranean, there still remains a vision gap on explicit social objectives and how to achieve them (Said and Chuenpagdee, 2019). As a result, the sustainability of small-scale fisheries, and by which means it will be achieved, remains entangled in Member State politics and hegemonies.

Part of the policy problem is that EU decision-makers, out of touch with local resource-based industries tend to perceive the small-scale sector as a diminishing 'sunset' sector, a thing of the past, which does not attract younger generations, and will thus rightly cease to exist. Hence, there is no vision of how the small-scale sector could benefit, and contribute to, the blue economy despite generating over $80 \%$ of fish-related jobs, and being a crucial component of the local economy both directly and indirectly through for example, tourism. With such a passive and ambivalent attitude at all levels of governance, it is likely that the small-scale sector will succumb to the massive pressures that it has been battling. We therefore argue that a fundamental rethinking of the capitalist model that governs the sustainability and future of fishing communities is needed.

By this we mean both an imaginative and active departure from the cyclical process of capitalist commodification supporting the unstoppable growth of the large corporate industries which has been shown to hamper many small-scale fisheries across the world (Pinkerton and Davis, 2015). This could be achieved through a 'redistribution' strategy that makes space for many parallel 'growths' and development paths, based on equity and inclusiveness. We call it

\footnotetext{
${ }^{7}$ http://www.eufundsmalta.gov.mt/content/open-call-project-proposals-under-european-maritime-and-fisheriesfund-emff-2014-\%E2\%80\%93-2020
} 
'regrabbing' because the fishing sector, as the pioneer user of the resources that are now privatised, requires to re-establish its access and rights to the resources to engage in parallel growth, as envisaged by the concept of 'diverse economies', where two parallel economies can be functional (Gibson-Graham, 2014). By regrabbing we also mean the implementation of social justice which plays an important role in defining degrowth as a means of 'giving back' the right of use to traditional key players in the marine area, and allowing them to participate on an equal footing in the local economy (D'Alisa et al., 2015). Ultimately, there is a policy choice that needs to be made in order to provide ways and means by which the governing bodies allow the community to 'take back the economy' in its hands. (Graham-Gibson et al., 2013). After all, the state must respond to the welfare needs of all those who have been dispossessed in order to be able to govern (Menon et al., 2018).

The transition could be facilitated by policy reforms which include better access for small-scale fishing enterprises such as access to quota and markets, as advised by the governance of tenure in the FAO Small-scale fisheries guidelines (FAO, 2015), and as discussed in detail by Smith et al (2019) where they recommend a framework for the allocation criteria of fishing rights for small-scale fisheries based on the principles of 'equity', 'preservation of cultural values', and 'ensuring the participation of marginalized groups' (Smith et al., 2019). This could be a way of re-imagining how fishing rights could be better aligned to support the resilience of the community. An illustration of how this can be implemented is the concept of a communal quota, as applied in Newfoundland Canada, where fishing rights have not been distributed to individual enterprises, but to the community. The aim was to enable the community to raise revenue from selling the quota to individual community members, with the wealth created by the resources to be reinvested by and in the community itself (Foley and Mather, 2016). This way of allocating rights and the wealth generated therein enabled the possibility of having parallel growths by community economies. In other words, growth, here, is based on sound business principles incorporating economic efficiency, but rewarding the community for meeting sustainable goals through ownership and governance of the rights to fish (Foley and Mather, 2016). This ideology stems from the concept of 'community economies', which suggests that the rebuilding of communities does not always mean to 'walk away' from capitalism, but to use more appropriate policy mechanisms to regulate excessive accumulation of capital and to filter benefits within the community via 'a new pattern of the surplus distribution' (St Martin, 2007). Further inspiration could be found in the social solidarity economy thinking (SSEs), which is conceptualized as a 'transformative citizen-led alternative to market-capitalism', focused on building an economy and society that serves people and planet, and which 'respects the diversity of local experience, history and culture' (RIPESS, 2015). 
In Malta, for example, community economies could be envisaged through reforms to government assistance and EU funding, to facilitate the establishment of tuna ranching farms leased to, and operated by, a co-operative community business or through producer organization systems that give fishers more market leverage on the value chain of their products (Pascual-Fernández et al., 2018). In this regard, it would be necessary for the government to monitor and intervene in the way the enterprise operates to ensure a fair share across the community. A similar aquaculture strategy has been implemented in Sri Lanka which was focused on small-scale operations through collective decision-making and a bottom-up management approach (Galappaththi and Nayak, 2017).

This model, which could easily fit the Malta's aquaculture blue growth strategy, has the capacity to empower the fishing community, improve their incomes, and reduce their dependency on other fisheries systems (such as demersal trammel-netting) which are to some extent overexploited. The reduction of fishing effort could also link well with the adoption of the MPAs through the right management framework for conservation of fish stocks. Other ways of how profits accrued from tuna could be redistributed to the community is through a system of royalties by which the communities, as owners of the quota, can lease it to established tuna ranching companies in return for royalties and economic benefits, which the community can then reinvest in seafood processing initiatives or other infrastructures, as has been implemented in the case of the Canadian shrimp (Foley et al., 2015). Profit redistribution mechanisms could also be foreseen in the vessel operations through a shared system in a way that attracts more locals from the fishing community to partake in the fishery.

Governance systems will need to be refreshed, with a view of bringing back the communities by rebuilding their capacities and resilience through the right policies and development measures. Such a transformation, however, would require changes in structures and institutions as well as mobilizing agency within the fishing communities to engage as the key actors in fishery management. Facilitating more representative fisher organizations either through new organizations, or by establishing corrective procedures within the existing cooperatives to monitor their governing roles, is fundamental. Notwithstanding the benefits that accrue with community-based management schemes, devolving the power and responsibility to individual citizens requires precautionary measures to ensure that these do not turn into extension of neoliberal rationalities (Bresnihan, 2019) susceptible to elite capture as has already been the case with the role of cooperatives taking the lead of decisions on behalf of the communities. This can also lead the way to the establishment of Fisheries Local Action Groups (FLAGs) (van de Walle et al., 2015) as one way of assembling the capacities needed for the diverse economies to be developed, also linking to other niches such as fishing tourism (Said, 2017). Through such institutions, the government can then initiate community-based 
governance strategies, also to oversee the implementation of marine spatial planning and MPAs with the fishers, such as through co-management arrangements.

We note that the changes in the system cannot be abrupt, but should involve a process of negotiation, especially with those (corporations and fishers in the upper circles) who are currently benefitting from the system and would oppose any changes that could inflict with their profit flows. Redistribution of wealth brings with it a spectrum of winners and losers, hence, a process of conflict resolution through social learning, the building of networks and linkages across scales could be a way of finding compromises that allow continued sustainable development. This stage could benefit from the role of transdisciplinary research approaches that provide in-depth reflection on the systems, and provide the insight to inform the necessary governance transformations (Chuenpagdee and Jentoft, 2018).

The role of the researchers, through transdisciplinary groups including different disciplines and members of the fishing community, is also important to provide the necessary bridging needed in the co-identification of problems, and co-implementation of solutions that match the complexities which surround small-scale fisheries (Said et al., 2018a). This engagement and sharing of ideas, about for example marketing strategies, or fisheries management systems, could be a process built on experiences, with which scientists together with fishing communities can 'rethink the economy with thick description and weak theory'...to come up with 'threads of hope that emerge into stories of everyday revolution' (Gibson-Graham, 2014: 147). These include bringing into light 'marginalized, hidden and alternative economic activities... to make them more real and more credible as objects of policy and activism' (Gibson-Graham, 2008). This could be done through action research that looks into the coproduction of new social enterprises, community supported production and marketing, and commons management.

Engaging policy-makers in the process would be instrumental, mostly to seek windows of opportunity, such as supranational policy instruments, for new ideas to be materialized. Timing is proper in this regard, as many things are happening, also in the context of EU where a focus towards new economies, diversification and community-management as new forms of governmentality provide a new foundation which the fishing communities can avail from. This process can be facilitated by the FAO Small-scale Fisheries Guidelines (FAO, 2015) through the recommendations on, for example, the implementation of 'governance of tenure in smallscale fisheries and resource management', such as legitimate practices in the allocation of fishing rights (5.4) and in the recognition for territorial fishing grounds (5.7) which permits fishers to practice their fishing activities and maintain a livelihood, rather than be arbitrarily evicted from their fishing grounds to make space for new marine uses (5.9). The FAO small- 
scale fisheries Guidelines provide a tool to improve the governance of the small-scale fisheries, and recently their alignment with the UN sustainable development goals has been perceived as fundamental for the sustainability of small-scale fisheries within the EU context and beyond (Said and Chuenpagdee, 2019).

\section{6) Conclusion}

Our research has shown how in different ways, the policies of ITQs, marine conservation and fleet restructuration have equated into a social tragedy that is driving an extinction cycle which will deprive future generations the opportunity to exist in a cohesive and vibrant culture and community economy that had once been integral to the social, economic and cultural fabric of the island. We claim that such a fragile economy typical of an island state must be treated with caution given that economic shocks can have large social problems, which might not be reversible. In this regard we argue that a blue degrowth agenda, through a re-grabbing policy that shares the wealth accrued from marine resources in more inclusive ways, and through the right governance systems at the national and local level is required. Controlling the forces of privatisation, which facilitate the capitalistic accumulation of natural resources as well as implementing marine conservation which includes rather than excludes small-scale fisheries, is a sound way of reviving the coastal communities and simultaneously restoring the longawaited replenishment of fish stocks.

We also recommend the development of initiatives which tend towards communalization rather than privatisation, such as new niche markets and tuna ranching investments for the fishing community, in a way that allows the community economy to compete on a level playing field within the existing markets and to flourish in parallel to existing economies, as conceptualized by the diverse economies theory. We insist that given the existing privatisation and enclosures in place, an overhaul is needed through a policy of regrabbing, otherwise, the potentials of community economies will remain only imaginary and tokenistic, and unable to provide conservation and growth strategies that match the social and economic profile of society at large. Pushing a communalization-based political economy requires careful considerations of the existing fragmented context which is fraught with distrust between fishers, and where a process of trust-building and reconciliation might be required. Such a process would benefit from academic and policy activism. Whilst the process might take time given that trust issues can be difficult to resolve, the action to move forward needs to be materialized before it is too late, before the traditional knowledge is lost, and before the fishing communities cease to exist.

This way, Malta can save both an important component of its maritime traditions, and be in a better position to reach the obligations set within the UN SDGs pertaining to ocean 
sustainability, quality of life, wellbeing, reduced inequalities and decent economic growth for all. Regrabbing as advocated here, is in our view the only way of achieving a balanced and sustainable fisheries sector that meets its obligations to the conservation of fish stocks and human communities. This will of course require a significant shift in political thinking in both EU member states and the EU itself, and therein lies the greatest challenge.

\section{References}

Agar, Michael H. 1996. The Professional Stranger: An Informal Introduction to Ethnography. 2nd Editio. Emerald Group.

425, C., 2001. CHAPTER 425 FISHERIES CONSERVATION AND. Malta.

Barbesgaard, M., 2018. Blue growth: savior or ocean grabbing? J. Peasant Stud. 45, 130 149. https://doi.org/10.1080/03066150.2017.1377186

Benjaminsen, T.A., Bryceson, I., 2012. Conservation, green/blue grabbing and accumulation by dispossession in Tanzania. J. Peasant Stud. 39, 335-355.

https://doi.org/10.1080/03066150.2012.667405

Bennett, N.J., Govan, H., Satterfield, T., 2015. Ocean grabbing. Mar. Policy 57, 61-68. https://doi.org/10.1016/J.MARPOL.2015.03.026

Berkes, F., Hughes, T.P., Steneck, R.S., Wilson, J. a., Bellwood, D.R., Crona, B., Folke, C., Gunderson, L.H., Leslie, H.M., Norberg, J., Nyström, M., Olsson, P., Österblom, H., 2006. Globalization, Roving Bandits, and Marine Resources 311, 1557-1558.

Blomeyer \& Sanz: Kim Stobberup, María Dolores Garza Gil, Aude Stirnemann-Relot, Arthur Rigaud, Nicolò Franceschelli, R.B., 2017. Small-scale fisheries and Blue Growth in the EU.

Borg, V.P., 2017. Fishermen on the brink. Times of Malta.

Bresnihan, P., 2019. Revisiting neoliberalism in the oceans: Governmentality and the biopolitics of 'improvement' in the Irish and European fisheries. Environ. Plan. A 51, 156-177. https://doi.org/10.1177/0308518X18803110

Bresnihan, P., 2017. The (Slow) Tragedy of Improvement: Neoliberalism, Fisheries Management \& the Institutional Commons. World Dev. https://doi.org/10.1016/j.worlddev.2017.09.017

Brown, G., Raymond, C.M., Corcoran, J., 2015. Mapping and measuring place attachment. Appl. Geogr. 57, 42-53. https://doi.org/10.1016/j.apgeog.2014.12.011

Camilleri, M., 2002. An Overview of the Conservative Management of Maltese Fisheries, in: APS Seminar Proceedings. pp. 41-66.

Caruana, M., 2015. Fascist rules in the fishing industry. Malta Today 3.

Chuenpagdee, R., Jentoft, S., 2018. Transforming the governance of small-scale fisheries. Marit. Stud. https://doi.org/10.1007/s40152-018-0087-7

Commission, E., 2017. Staff working document on Blue Growth.

Coria, J., Calfucura, E., 2012. Ecotourism and the development of indigenous communities: The good, the bad, and the ugly. Ecol. Econ. 73, 47-55. https://doi.org/10.1016/j.ecolecon.2011.10.024

Costanza, R., Kubiszewski, I., 2014. Creating a Sustainable and Desirable Future. World 
Sci. https://doi.org/10.1142/8922

D’Alisa, G., Demaria, F., Giorgos, K., 2015. Degrowth A Vocabulary for a New Era.

Davis, R., 2015. 'All in': Snow crab, capitalization, and the future of small-scale fisheries in Newfoundland. Mar. Policy 61, 323-330. https://doi.org/10.1016/j.marpol.2015.04.008

Dimech, M., Darmanin, M., Philip Smith, I., Kaiser, M.J., Schembri, P.J., 2009. Fishers' perception of a 35-year old exclusive Fisheries Management Zone. Biol. Conserv. 142, 2691-2702. https://doi.org/10.1016/j.biocon.2009.06.019

Donkersloot, R., Menzies, C., 2015. Place-based fishing livelihoods and the global ocean: the Irish pelagic fleet at home and abroad. Marit. Stud. 14, 20. https://doi.org/10.1186/s40152-015-0038-5

Duffy, R., 2002. A Trip Too Far: Ecotourism, Politics and Exploitation, 1st editio. ed. Routledge.

European Environment Agency, 2019. Status of marine fish and shelflish in European seas. Copenhagen, Denmark.

FAO, 2015. Voluntary Guidelines for Securing Sustainable Small-Scale Fisheries.

Foley, P., Mather, C., 2016. Making Space for Community Use Rights: Insights From "Community Economies" in Newfoundland and Labrador. Soc. Nat. Resour. 29, 965980. https://doi.org/10.1080/08941920.2015.1089611

Foley, P., Mather, C., Neis, B., 2015. Governing enclosure for coastal communities: Social embeddedness in a Canadian shrimp fishery. Mar. Policy 61, 390-400.

https://doi.org/10.1016/j.marpol.2014.11.009

Galappaththi, E.K., Nayak, P.K., 2017. Two faces of shrimp aquaculture: commonising vs. decommonising effects of a wicked driver. Marit. Stud. 16. https://doi.org/10.1186/s40152-017-0066-4

Gibbs, M.T., 2007. Lesser-known consequences of managing marine fisheries using individual transferable quotas. Mar. Policy 31, 112-116. https://doi.org/10.1016/j.marpol.2006.05.009

Gibson-Graham, J.K., 2014. Rethinking the Economy with Thick Description and Weak Theory. Curr. Anthropol. 55, S147-S153. https://doi.org/10.1086/676646

Gibson-Graham, J.K., 2008. Diverse economies: performative practices for 'other worlds'. Prog. Hum. Geogr. 32, 613-632.

https://doi.org/https://doi.org/10.1177/0309132508090821

Gidron, Noam; Ziblatt, D., 2019. Center-Right Political Parties in Advanced Democracies. Annu. Rev. Polit. Sci. 22, 17-35.

Graham-Gibson, J., Cameron, J., Healy, S., 2013. Take Back the Economy: An ethical guide for transforming our communities. University of Minnesota Press.

Gritzas, G., Kavoulakos, K.I., 2016. Diverse economies and alternative spaces: An overview of approaches and practices. Eur. Urban Reg. Stud. 23, 917-934. https://doi.org/10.1177/0969776415573778

Hadjimichael, M., 2018. A call for a blue degrowth: Unravelling the European Union's fisheries and maritime policies. Mar. Policy 94, 158-164. https://doi.org/10.1016/j.marpol.2018.05.007

Hadjimichael, M., 2015. Interactive Governance for Small-Scale Fisheries, Interactive 
Governance for Small-Scale Fisheries: Global Reflections. Springer. https://doi.org/10.1007/978-3-319-17034-3

Harvey, D., 2004. The 'new' imperialism: accumulation by dispossession. Social. Regist. 40, 63-87. https://doi.org/10.1215/01642472-18-1_62-1

Hill, A., 2017. Blue grabbing: Reviewing marine conservation in Redang Island Marine Park, Malaysia. Geoforum 79, 97-100. https://doi.org/10.1016/j.geoforum.2016.12.019

Host, J., 2015. Governing Through Markets: Societal Objectives, Private Property Rights and Small-Scale Fisheries in Denmark, in: Jentoft, S., Chuenpagdee, R. (Eds.), Interactive Governance for Fisheries. pp. 319-336. https://doi.org/10.1007/978-3-319-17034-3

The Malta Independent., 2005. Green Light for fish farm - 2005, Retrieved on

Jacobsen, R.B., Delaney, A.E., 2014. When social sustainability becomes politics perspectives from Greenlandic fisheries governance. Marit. Stud. 13, 6. https://doi.org/10.1186/2212-9790-13-6

Jentoft, S., 2017. Small-scale fisheries within maritime spatial planning: knowledge integration and power. J. Environ. Policy Plan. 7200, 1-13. https://doi.org/10.1080/1523908X.2017.1304210

Jones, P.J.S., 2009. Equity, justice and power issues raised by no-take marine protected area proposals. Mar. Policy 33, 759-765. https://doi.org/10.1016/j.marpol.2009.02.009

Kallis, G., March, H., 2015. Imaginaries of Hope: The Utopianism of Degrowth. Ann. Assoc. Am. Geogr. 105, 360-368. https://doi.org/10.1080/00045608.2014.973803

Knutson, P., 2017. Escaping the corporate net: Pragmatics of small boat direct marketing in the U.S. Salmon fishing industry of the Northeastern pacific. Mar. Policy 80, 123-129. https://doi.org/10.1016/j.marpol.2016.03.015

Koning, J., 2002. Social sustainability in a globalizing world: context, theory and methodology explored, in: More on MOST. pp. 63-90.

Lloret, J., Cowx, I.G., Cabral, H., Castro, M., Font, T., Gonçalves, J.M.S., Gordoa, A., Hoefnagel, E., Matić-Skoko, S., Mikkelsen, E., Morales-Nin, B., Moutopoulos, D.K., Muñoz, M., dos Santos, M.N., Pintassilgo, P., Pita, C., Stergiou, K.I., Unnal, V., Veiga, P., Erzini, K., 2016. Small-scale coastal fisheries in European Seas are not what they were: Ecological, social and economic changes. Mar. Policy. https://doi.org/10.1016/j.marpol.2016.11.007

Martin, I., 2019. Malta's tuna catch gets unprecedented quota increase. TOM.

Martínez-Alier, J., 2012. Environmental justice and economic degrowth: An alliance between two movements. Capital. Nature, Social. 23, 51-73. https://doi.org/10.1080/10455752.2011.648839

Martínez-Alier, J., Pascual, U., Vivien, F.D., Zaccai, E., 2010. Sustainable de-growth: Mapping the context, criticisms and future prospects of an emergent paradigm. Ecol. Econ. 69, 1741-1747. https://doi.org/10.1016/j.ecolecon.2010.04.017

Menon, A., Sowman, M., Bavinck, M., 2018. Rethinking capitalist transformation of fisheries in South Africa and India. Ecol. Soc. 23. https://doi.org/10.5751/ES-10461-230427

Moore, J., 2016. Anthropocene or Capitalocene?: Nature, History, and the Crisis of Capitalism. PM PRESS.

MSDEC, 2013. Fishing Effort Adjustment Plan for Bottom otter trawl fishery. 
Office, N.S., 2015. News Release Aquaculture: 2014, 2015. Malta.

Pace, F., 2019. €100,000 for boat restoration scheme. TVM Curr. Aff. 1-4.

Pascual-Fernández, J., Pita, C., Josupeit, H., Said, A., Garcia Rodriguez, J., 2018. Markets, Distribution and Value Chains in Small-Scale Fisheries: A Special Focus on Europe, in: Ratana, C., Jentoft, S. (Eds.), Transdisciplinarity for Small-Scale Fisheries Governance. Springer, pp. 141-162.

Pauly, D., 2017. A vision for marine fisheries in a global blue economy. Mar. Policy 0-1. https://doi.org/10.1016/j.marpol.2017.11.010

Pinkerton, E., Davis, R., 2015. Neoliberalism and the politics of enclosure in North American small-scale fisheries. Mar. Policy 1-10. https://doi.org/10.1016/j.marpol.2015.03.025

RIPESS, 2015. Global Vision for a Social Solidarity Economy: Convergences and Differences in Concepts, Definitions and Frameworks. Glob. Vision-RIPESS 1-16.

Sabau, G., van Zyll de Jong, M., 2015. From unjust uneconomic growth to sustainable fisheries in Newfoundland: The true costs of closing the inshore fishery for groundfish. Mar. Policy 61, 376-389. https://doi.org/10.1016/j.marpol.2014.11.012

Said, A., 2017. Are the Small-Scale Fisheries Guidelines Sufficient to Halt the Fisheries Decline in Malta?, in: Jentoft, S., Franz, N., Barragan Pallidines, J.., Chuenpagdee, R. (Eds.), The Small-Scale Fisheries Guidelines Global Implementation. Springer.

Said, A., Chuenpagdee, R., 2019. Aligning the sustainable development goals to the smallscale fisheries guidelines: a case for EU governance. Mar. Policy.

Said, A., Chuenpagdee, R., Jentoft, S., 2018a. The Principles of Transdisciplinary Research in Small-Scale Fisheries, in: Chuenpagdee, R., Jentoft, S. (Eds.), Transdisciplinarity in Small-Scale Fisheries Governance. SPRINGER.

Said, A., MacMillan, D., Campbell, B., 2018. Crossroads at sea: Escalating conflict in a marine protected area in Malta. Estuar. Coast. Shelf Sci. 208. https://doi.org/10.1016/j.ecss.2018.04.019

Said, A., MacMillan, D., Schembri, M., Tzanopoulos, J., 2017. Fishing in a congested sea: What do marine protected areas imply for the future of the Maltese artisanal fleet? Appl. Geogr. 87. https://doi.org/10.1016/j.apgeog.2017.08.013

Said, A., MacMillan, D., Tzanopoulos, J., 2018b. The contested commons: The failure of EU fisheries policy and governance in the Mediterranean and the crisis enveloping the small-scale fisheries of Malta. Front. Mar. Sci. 5, 300.

https://doi.org/10.3389/FMARS.2018.00300

Said, A., Tzanopoulos, J., MacMillan, D., 2016. Bluefin tuna fishery policy in Malta: The plight of artisanal fishermen caught in the capitalist net. Mar. Policy 73. https://doi.org/10.1016/j.marpol.2016.07.025

Said, A., Tzanopoulos, J., MacMillan, D., 2016. Bluefin tuna fishery policy in Malta: The plight of artisanal fishermen caught in the capitalist net. Mar. Policy 73, 27-34. https://doi.org/10.1016/j.marpol.2016.07.025

Smith, S.L., Battista, W., Sarto, N., Fujita, R., Stetten, D.C., Karasik, R., Burden, M., 2019. A framework for allocating fi shing rights in small-scale fi sheries. Ocean Coast. Manag. 177, 52-63. https://doi.org/10.1016/j.ocecoaman.2019.04.020

St Martin, K., 2007. The difference that class makes: Neoliberalization and non-capitalism in the fishing industry of new england. Antipode 39, 527-549.

https://doi.org/10.1111/j.1467-8330.2007.00538.x 
Sumaila, U.R., 2010. A Cautionary Note on Individual Transferable Quotas. Ecol. Soc. 15, 36.

TOM, 2019. Fisheries board has not met for 20 months - minister. Times of Malta.

TOM, 2014. Dwejra fishing nets spark calls for better protection 1-10.

TOM, 2011. Trammel nets still reign supreme. Timesofmalta.com.

TOM, 2010. Divers call for better enforcement, protection measures at dive sites 1-2.

TOM, 2007a. Divers face risks at artificial reefs as authorities fail to act. Times of Malta.

TOM, 2007b. Fishing near wrecks must stop , says minister. Times of Malta.

van de Walle, G., Gomes da Silva, S., O'Hara, E., Soto, P., 2015. Achieving Sustainable Development of Local Fishing Interests: The Case of $P$ ays $d$ "'</i> A uray flag. Sociol. Ruralis 55, n/a-n/a. https://doi.org/10.1111/soru.12097 